\title{
Literature Review on Dynamics and Determinants of Dividend Policy in Pakistan Evidences from Pakistan
}

\author{
Kashif Islam ${ }^{1,2 *}$, Ahmad Raza bilal ${ }^{2}$, Ch. Abdur Rehman ${ }^{2}$ and Muhammad llyas ${ }^{2}$ \\ ${ }^{1}$ Department of Commerce, Govt. College of Commerce, Five Ways Chowk, Liaqat Road, Sahiwal, Punjab, Pakistan \\ ${ }^{2}$ The Superior College, Lahore, Pakistan
}

\begin{abstract}
The natural approach is undertaken by all the researchers regarding critical literature review is to make a target oriented attempt to categorize all the existing writings in to different relevant groups or classifications that fall within our area of interest and to find out main pillars of our discussion to support our research gaps as a point of helping argument in our study. Identifying all the principal authors of different research works by "backtracking" from a well-known, recent contribution to the oldest contributions in the same area of work. Same is the case with the present study, where literature review of all relevant work has been rigorously attempted to find out research gaps or research questions.
\end{abstract}

Keywords: Dividend smoothing; Dynamic of dividend; Stock dividends; Lobbying effect; Pork effect; Ownership effects

\section{Introduction}

It is to be noted that careful identification and selection of different themes and issues based on some general sampling of prevailing literature is the basis of creation of some effective, well synchronized, well planned, well-structured and a complete and comprehensive literature review. This goes automatically towards the use of inductive approach which is followed in the literature which is based on the idea created by Papineau's tree. This concept focuses mainly on the descending order of main themes to segregate those themes which are focal point of all the research work conducted within main programme [1]. Also, the main concepts of research are written down in a particular hierarchy sequence within a chronological order to be more useful and result oriented for effective understanding and development of new literature. The main importance of this literature review is to summarize the internal body of the literature using Papineau's tree to extract the main contributions in the existing framework in order to purify and trim down the existing literature.

Dividend smoothing, being a delicate tool, nevertheless relatively a hundred years old phenomenon of the modern business world. The footsteps can be traced back as early as in the 1950's as discussed by Lintner in 1956 for the very first time. He concluded that firms give weight to a 'Stable Dividend Policy' after conducting personal interviews of managers of 28 selected companies. This is done in order to match the gap between the target set by the firm and the actual payout ratio. As a result of this technique, the volume of dividend will be stream-lined as desired by covering the bad effects of macroeconomic issues.

Miller and Modigliani [2] found the least effects of dividend policy on the investment conclusion in business, simply on the ground that in case of emergencies, shares could be sold for cash. In simple words, they are to be used as tool for 'transaction motive' as classification given by J.M. Keynes.

Apart, the dividend policies (aggressive or moderate) are understood as the positive signs of financial stability and reliability [3]. Positive signals are inferred for investors, if dividends are portrayed in upward graphically. Because the dividends are considered as cash flows representing the outcome for investors [4].

Our discursion on dividends, its implication and importance on smoothing is not an old phenomenon of the modern business world. The footsteps can be found as old as in the era of late 1950's as discussed by Linter in 1956 for the very first time. He concluded that firms give weight to a 'Stable Dividend Policy' after conducting personal interviews of managers of 28 selected companies. This is done in order to match the bridge gap between the goal set by the firm and the actual dividend payout ratio. As a result of this technique, the volume of dividend will be stream lined as desired by covering the bad effects of macroeconomic issues.

Miller and Modigliani [2] found the least effects of dividend policy on the investment conclusion in business, simply on the ground that in case of emergencies, shares could be sold for cash. In simple words, they are to be used as tool for 'transaction motive' as classification given by J.M. Keynes.

Dividend stability has been worked out and investigated by many old and current researchers by capitalizing the Linter's idea. No doubt, on the other hand, the dividend irrelevance theorem does exist at its original place. As the Linter's model has been referred in the research workings of Rozycki, Chemmanur et al., Leary and Michaely, and $\mathrm{Al}-$ Yahyea et al. [5-8].

Since 1950's, the postulates of dividend smoothing can be observed that stable and steady policies of dividends are always encouraged and bridge the gap between actual and potential streams of payout and yield ratios of dividend like cash or stock dividends in general [9].

As investor's investment decisions are mostly based on amount and type of dividends. Furthermore, the current study would investigate and probe into the various modules of dividend smoothing in detail and present into four major categories. The model presented by Lintner can be traced out in the financial research standards. Miller and Modigliani [2] have pointed out many years ago that any type of dividend policy normally does not play any role manipulate any investor's decision. The

*Corresponding author: Kashif Islam, Department of Commerce, Govt. College of Commerce, Five Ways Chowk, Liaqat Road, Sahiwal, Punjab, Pakistan, Tel: 03006900351, Email: kashifislamroyal@hotmail.com

Received June 27, 2017; Accepted July 06, 2017; Published July 11, 2017

Citation: Islam K, Bilal AR, Rehman CA, Ilyas M (2017) Literature Review on Dynamics and Determinants of Dividend Policy in Pakistan Evidences from Pakistan. Review Pub Administration Manag 5: 218. doi:10.4172/23157844.1000218

Copyright: $\odot 2017$ Islam K, et al. This is an open-access article distributed unde the terms of the Creative Commons Attribution License, which permits unrestricted use, distribution, and reproduction in any medium, provided the original author and source are credited. 
reason is, simply to sell their investment of shares to any one if they in need of emergency cash requirements.

\section{Determinants of Dividend Policy}

A long list of variables exists in the literature which are called and characterized as determinants of dividend policy. They are listed as follows:

(i) Nature or type of industry or area of work

(ii) Age of corporation or number of working years in specific industry

(iii) Extent of share distribution or profit distribution ratio

(iv) Need for additional capital or financing methods in case of need

(v) Business cycles or trade cycles or economy cycle

(vi) Changes in government policies or political stability

(vii) Trends of profits or profit margin

(viii) Taxation policy or rates of taxes or slab rates

(ix) Future requirements or future scope or future needs

(x) Cash balance or liquidity position or volume of cash

Some types of legal, moral and financial bindings or considerations are vital regarding dividend declarations. The pre-condition for dividend declaration is the profits of the company. If profits are not earned by the company, we cannot declare and pay dividends legally without the impairment of capital amount invested by the shareholders. But, in reality, there is a huge list of factors which directly or indirectly influence the level of dividend regarding its declaration and distribution. These financial considerations/constraints play a vital role in arriving at a desirable decision for the establishment of a reasonable policy of how much to be paid to shareholders.

\section{Legal Rules Governing Payments of Dividends}

The most vital thing is that dividend will be illegal if the share capital would reduce after the payment of this dividend. This is to be noted that it is legal binding and must be paid out of its capital surplus funds available. As positive revaluation reserve, definitely create a capital surplus, but it may be the first step of financial embezzlement with different stake holders resulting in an illegal activity. The need of dividend payments gives strength to corporations to safeguard the interest of the creditors. Dividends must be paid out of profits when the business is solvent and payments will not make the business insolvent. It is the duty of the BOD to take into consideration all the corporate laws before they declare and pay dividends. The company can delay and defer the distribution of dividend in cash, with the intension of strengthening the current financial position of the enterprise by declaring the stock dividend or bonus shares as it deems fit and necessary.

We conclude that judgment of management is of prime importance regarding the decision of dividends since it is not the compulsory legal binding for the management. A balanced and rational financial understanding is vital in weighing all the factors affecting the company policy.

\section{Stock Dividend or Bonus Shares}

A distribution of shares/stocks in place of cash payment to the existing shareholders on a pro-rata basis at or normally below the current market value is called stock dividends. It results in the transfer of funds with the different accounts of stock holder's equity section of the balance sheet where funds are transferred from any accumulated earnings (share premium, reserve funds, general reserves, dividend equalization funds etc.) or any other surplus or revaluation account to the company's share capital account. In simple words, the reserves are capitalized with the intention of transferring the ownership of those funds to the ultimately residual owners. In this case the equity increases while the cash level of the company remains unchanged by making a part of retained earnings' as 'a part of fixed capitalisation'.

\section{Reasons for Declaring Stock Dividends}

The two solid grounds why directors declare stock dividends are as follows

(1) Sometimes, in order to facilitate the broader and easy access to ownership and to reduce the market value to a minimum acceptable level so that investors with lower funds may also be in a position to buy our shares.

(2) The company's cash position is always very vital and in some special cases, we should come to know that earnings may not be divided among the shareholders. So, we should come to know that declaration of stock dividend will give the shareholders the confidence and their company is going well and their investments are increasing and consolidating with the intention of increasing the investment in the company. If the stockholders required additional cash, then they can sell their investments in the open market to earn money.

(3) Stock dividends are declared with the intention of issuing the stocks to distribute the old accumulated surplus among the old shareholders.

\section{Literature Review and Hypothesis Development}

\section{Institutional development, state ownership and level of cash dividends}

Opler et al. [10] conducted a result oriented study regarding the cost and benefit analysis of volume of cash. The price of cash level will be lower rate of profit earned on the assets involved in business operations. On the other side of the picture, the cash level of the company has mainly two benefits to the company. At the first place, the firm can save transaction costs to be incurred on the funds rose to finance operational or strategic decisions of the firms and does not have enough liquidity to make operational payments. While on the other hand, the firm can use these surplus funds to finance its different investment projects if other sources of the financing may not be available or then it will be very costly.

More recent studies, are now focusing on the relationships between level of cash holdings (cash dividends) and corporate governance mechanism and systems or so [11-14].

Myers and Rajan [15] identified that cash being the liquid one asset is more susceptible to be expropriated by the politicians. As the politicians have to pay nothing special to convert the liquid cash into personal consumption. So, in order to protect the cash balance of the company from being expropriated, the manager take the U-turn and try to invest into fixed assets just to convert the liquidity into the most liquid form into the less liquid form, being the harder one to be extracted easily. This option is more workable for those firms which are in more danger of being politically extracted one.

The country level indices available regarding the level of corruption to measure the real extent, threat or density of political extraction, Caprio finds that where the corruption levels are high (the relatively 
higher threat level of political exploitation), they tend to less hold of cash diverting the cash to various short term and long term investments in fixed assets than those firms where the corruption levels are low. The previous research work indicates that there is a no significant level of institution development across different regions of Pakistan. Different anecdotal evidences across different regions are of the view that degree of or more properly the level of resource mis-utilization across Pakistan is different. Hence, the political extraction hypothesis, we can write the first part of the first hypothesis can be written as:

H1a: Firms in provinces with more well-established structures of institutions have larger amounts for cash dividends than firms in the provinces with less developed/ less structured institutions

In addition, Pakistan is a country, where both types of firms controlled by the government and those controlled by the private entrepreneurs. Here, non-state-controlled enterprises are more prone to political misappropriations than are state controlled firm (public sector firms). For example, Johnson and Brandt andLi document that non-state controlled firms are often pay higher rates of taxes and get less privileges in bank financing. Based on the above conjecture or argument, the non-state firms called private firms (family owned firms), have more incentives to hold lower level of cash reserves than the state controlled firms having more protection for their assets. The second part of the first hypothesis can be stated as follows:

H1b: Non-state-controlled firms (Family owned/private firms) have smaller cash holdings for dividends than state-controlled firms

If we combine these two above sub-hypotheses, then the effect of institutional development on dividends will be expected to vary across the public and private sector. It is worth mentioning here that political mis-appropriation is always lower when the institutional internal environment is comparatively being more business friendly, then it will definitely favor the non-state controlled firms to a larger extent showing the positive relationship between institutional development and cash holdings are more vital for non-state controlled firms. So, after discussion, the third part of the first hypothesis will be narrated in the following statement:

H1c: A positive relationship between institutional structural development and level of cash is more prominent for NSC firms rather than for SC firms

The precautionary motive being one of the motives discussed by Keynesian theory, shows the level of holding cash with the combine effects of institutional development (ID) and NSC firms, and their impact on the 'threat of political expropriations'. Most of the previous studies show that NSC firms face different levels of discriminations against the formal use of financing channels [16,17]. The development of institutions minimizes the financing frictions faced by NSC firms [17]. The quality/talent of managers regarding policy implementation gives more investment opportunities to NSC firms, as they are more willing to work, expand and absorb more fluctuations to win more business contracts than their competitors.

The firms having more investment options coupled with higher financing abrasion or resistance are always in need of more cash volume to pay dividends as a precautionary purpose [10]. Any significant change in institutional development has more impact on NSC firms, being more prone to financing options. So, the precautionary motive hypothesis, an alternate or reverse hypothesis will be written as:

H1: More developed institutions of provinces promote smaller dividend and vice versa.

\section{Role of political connections}

Political connections have mixed effects on the firm performance. It acts as bone and a bane at the same time being a mixed blessing for all types of NSC firms as a whole. The most recent and up to date wave of critical literature review has pointed out the worth and value to political connectedness to different connected firms around the world. Most of the studies are exploring that PC may be valuable or detrimental one for the NSC's. Minimum tax rates, priority in capital accumulation, favorable regulatory, monetary, fiscal and commercial benefits are directly linked with the political affiliations in one way or the other way. The lighter taxation is the main outcome of political nexus called 'Ghuanxi' in china. No doubt in Pakistan, political merger gives benefits in a variety of ways. Fan has investigated and pointed out that more than $1 / 4^{\text {th }}$ of CEO's of private companies were previously serving any government department in China. Same is the case with Pakistani firms where mostly, the CEO's have political or government back ground due to 'lobbying and pork effects.' Most of the firms are involved in legislation or law making through their top officials who are actively participating in the politics in the form of MPA's or MNA's.

The main aim is how to arrange the loans for their entities with minimum formalities and minimum debt services. Faccio et al. [18] is of the view that one hidden or more daring view is that it is an open secret that political nexus facilitates in lower danger of asset extraction by the government (politicians), as the management of NSC firms is also the part of the government (Politicians). With the help of this perspective, we can advance towards the first part of second hypothesis that NSC firms having political background may hold more cash than non-connected political firms.

H 2a: NSC firms with political background have higher cash volumes

Previous workings on this dimension found that connections with political parties are very common in developed and less developed countries. The research indicates that even UK and USA, companies give funds, donations and other facilities to the different political parties called 'legal bribery' in their local frame work. And there are certain criteria through which the experts can judge whether a particular company is politically connected or not. These criteria have been developed after extensive critical review of literature available containing different studies conducted in USA, Malaysia, China and India.

Faccio et al. [18] concluded that the worth and value of political association changes over time with the change in institutions, infrastructure and economic conditions of the country. Similarly, Chiang et al. and Wang et al. $[11,17]$ found that creating more and more political connections is essential and vital for NSC firms located in the areas where over all the institutions are less developed. Wu investigated that advantages of political annexure accrue only to NSF firms.

There is a direct nexus between the institutional development levels and the amount of political extraction/connectedness and jointly affect the value of politically connected (PC) firms. The main difference is the level of cash volumes will be high in the areas having developed and well-structured institutions having more engagements in politics. The second part of the second hypothesis is written as:

H2b: The positive effect of developed and well-structured institutions on volume of cash for dividends is less prominent for PC firms

\section{Role of corporate governance}

We begin the idea discussed in the book 'Wealth of Nations' by 
Alferd Marshal in 1776, that managers, being the fund managers of other people's money are not efficient and vigilant for their funds rather than their own money. So, it depends on so many other factors which are vital in the management of owner's wealth maximization concept.

Different definitions have been devised by the different experts in whom various aspects of Corporate Governance Mechanism (CGM) and Corporate Governance Structures (CGS) have been covered. In the words of Cadbury Code, it is a system in which companies are directed and controlled. Another perspective of CGM and CGS is the set of all synchronized mechanisms to be implemented and used by the external investors (shareholders) to protect their concerns, rights and interests against the insiders, called controlling or major shareholders and managers being first or second line managers [19]. The OECD defined CG, which develops a strong set of interactions or working relationships among all the members of its stakeholders. CG facilitates a structure and a mechanism, which helps to establish the objectives of the company are set out, means and resources to achieve those organizational objectives with effective implementation of workable processes by determining and monitoring the overall operations of the company. While Banks defined CG as an integrated framework in the corporation for and on the behalf of its all relevant stakeholders.

La Porta et al. [19] state that the main outcome of corporate governance is return on invested resources of the stakeholders. In simple words, we can define as that both the investors and creditors of the company gain their legitimate homecoming on their outlay. The main purpose of agency theory has the main focus on stakeholders. The agency theory narrates that CG is the method of the enterprise, especially the private limited companies, how they are managed and formal procedures of accountability of the manager's deeds towards the residual owners. (Dictionary of Accounting, Oxford University Press).

Beiner and Schmid [20] state that if the firms are better governed, better managed, the result will be higher value (higher net worth) with improved accountability and responsibility. It is worth mentioning that board of governance, directors and all shareholders and the firm itself gets help from the internal corporate governance structural and mechanisms tools and techniques to minimize the risks related with corporate issues to enhance the value of the firms.

Asymmetry level of Information and managerial signalling Theory: To create the bond between principals (shareholders) and agents (managers) in modern business world, all the previous research work mainly focuses on information asymmetry with the help of signaling theory as a supporting element to magnify owner's investment [21]. Managers being the internal part of the company are naturally in a better position regarding the true picture of company, including the private information which is vital for company success not only existing shareholders but also for the potential and prospective shareholders [22,23].

While making new portfolio decisions regarding its selection, evaluation, revision and modification, there is a special say of prospective shareholders, we normally face two challenges. Firstly, the probable new investors are in front of the challenge of selection of those firms with the most dynamic management (adverse selection of persons). Secondly, same is the case with the agency theory, they meet head-on with the problem of ensuring that managers do not exploit the supreme information to expropriate the excessive perquisites and do not invest into their pet projects [23]. Moreover, Jensen and Meckling and Mishkin et al. [24,25] suggest that there are two possible options like balanced or rational shareholder and market uncertainty or market ups and down.
Stewardship theory: The basic theme behind this theory is to make various assumptions regarding the behavior of top management. Firstly, this theory assumes that most of the top managers usually spend their lives with the company and they have better understanding of the business affairs as compared to the outsiders and they can make supreme decisions [26]. Secondly, better decision making is the direct result of formal and informal knowledge of the managers. Finally, agency costs can be minimized only due to the fear of damaging their potential future $[27,28]$. So, by and large, the followers of this theory show that financial efficiency of the business enterprises is directly associated with the different corporate governance practices that provide more powers with respect to the position of directors and chairman [26].

Agency theory: Agency theory is relatively a dominant subject and is very commonly used within corporate finance and especially in the field of corporate governance studies and analysis [29]

It is commonly observed that most majority of the approached used in CG are based on the idea of separation of ownership and control from management based on the initial research work of [30]. As the alignment of interests of both counter parts has been very critical issue $[24,27]$. Both the parties try to increase their personal benefits as the main effort of both of them. All this was documented and arranged by Adam Smith in the $18^{\text {th }}$ century in his literary work on joint stock companies (cited by Cadbury, p.4):" being the supervisor or manager of other people's money, they cannot be expected to watch and look after with the same vigilance with which they can watch over their own interests".

H0: Good Corporate governance strategies affect dividend payouts

\section{Relationship between dividend and investment decisions}

Mille and Modigliani [2] gave an idea that dividend policy normally has no effect on the value of firm in perfectly competitive market. The reason is very simple that the shareholders can produce and develop any kind of dividend policy effects by selling equity shares. The work of Fama and Jensen [28] was re considered and replicated by Miller and Modigliani [2] in order to test the inter dependence of investment and dividend payouts. Morgan [27] replicated the work of Fama and Jensen [28] in order to test the strategic and long term aims of investments and payouts ratios of companies. However, they establish and pointed out that the parent companies will not particularly highlight the nonavailability of resources that will be invested in the shares.

H0: Level of investments is not directly related with dividend declaration

\section{Taxes and dividends}

Taxes play a vital role in the dividend payments. We should keep in mind that taxes are paid on profits and after the payment of taxes we get Earnings After Tax (EAT). From EAT, we pay dividends to the preferred shareholders and then we pay dividends to the common shareholders in the second attempt. Tax rates are always very high in case of corporate levels. There are so many legal formalities which are to be followed and fulfilled by the corporate bodies to pay dividends. If the taxes are high, the resulting amounts called 'divisible profits' for the preferred and common shareholders will be lowered and subsequently it will create panic among the common shareholders who are called the real or the residual owners of the companies. It is worth mentioning here, that there is normally no change of situation for preferred shareholders as they are normally within different categories like cumulative or non- 
Citation: Islam K, Bilal AR, Rehman CA, llyas M (2017) Literature Review on Dynamics and Determinants of Dividend Policy in Pakistan Evidences from Pakistan. Review Pub Administration Manag 5: 218. doi:10.4172/2315-7844.1000218

cumulative, participating or non-participating, callable or non-callable, convertible or non-convertible or so on. The threat is for the common or ordinary shareholders. So, the hypothesis regarding tax-effect recommends and puts forward that lower the dividend payments, lower the cost of capital resulting an increase in higher prices of shares which will contribute towards the achievement of maximum worth of the firms. The theme behind this argument is very common that is capital gains are taxed at lower rates while dividends are taxed at higher ones.

Therefore, relatively higher or greater returns (pre-tax risk adjusted) are desirable by the investors to consolidate having upper dividend yields.

\section{Conclusion}

We can conclude that the foundation of hypothesis called 'posited tax-effect' is the direct relationship between pre-tax returns on stocks and yields related dividends payouts. In contrast, the researchers like Booth and Cleary posit that most of the times in developing countries having more bank minded and financial system oriented, as compared to the firms of UK and USA. So, the above discussion has two dimensions i.e., one is favoring that tax rates have no effects on dividend payments while the other point of view is that dividends are directly influenced by rates of taxes.

H1: Taxes have no direct and significant effect on dividend payout ratios ratios

H2: Taxes have direct and significant effect on dividend payout

\section{References}

1. Ryan B, Scapens RW, Theobald M (2002) Research method and methodology in finance and accounting, Thompson, London.

2. Miller MH, Modigliani F (1961) Dividend policy, growth and the valuation of shares. The Journal of Business 34: 411-433.

3. Gombola MJ, Liu FY (1993) Considering dividend stability in the relation between yields and stock returns. J Financ Res 139-150.

4. Chen L, Da Z, Priestley R (2010) Dividend smoothings and predictability.

5. Rozycki JJ (1997) A Tax motivation for smoothing dividends. The quarterly review of economics and finance. pp. 563-578.

6. Chemmanur TJ, He J, Hu G, Liu H (2010) Is dividend smoothing universal? New insights from a comparative study of dividend. Journal of Corporate Finance. 16: 413-430.

7. Leary M, Michaely R (2011) Determinants of dividend smoothing: Empirical evidence. Rev Financ Stud. pp.1-55

8. Al-Yahyea KH, Pham TM, Walter TS (2011) Dividend smoothing when firms distribute most of their earnings as dividends. Applied Financial Economics (AFE). pp. 1175-1183.
9. Lintner J (1956) Distribution of incomes of corporations among dividends, retained earnings, and taxes. Am Econ Rev 46: 97-113.

10. Opler T, Pinkowitz L, Stulz R, Williamson R (1999) The determinants and implications of corporate cash holdings. J Financ Econ 52: 3-46.

11. Chiang CW, Pai YT, Tseng YH, Chen CC, Chuang CB (2009) U.S. Patent No. D588,126. Washington, DC: U.S. Patent and Trademark Office.

12. Dittmar A, Mahrt-Smith J, Servaes $H$ (2003) International corporate governance and corporate cash holdings. J Financ Quant Anal 38: 111-133.

13. Kalcheva I, Lins KV (2007) International evidence on cash holdings and expected managerial agency problems. Rev Financ Stud 20: 1087-1112.

14. McElroy D, Walsh C, Markwick AJ, Cordiner MA, Smith K, et al. (2013) The UMIST database for astrochemistry 2012. Astron Astrophys 550, A36.

15. Myers SC, Rajan RG (1998) The paradox of liquidity. Q J Econ 113: 733-771.

16. Allen RM, Lockman AB (2005) Single-station earthquake characterization for early warning. B Seismol Soc Am 95: 2029-2039.

17. Wang J, Li R, Yu C, Li Y, Lam TW, et al. (2009) SOAP2: An improved ultrafast tool for short read alignment. Bioinformatics 25: 1966-1967.

18. Faccio M, Masulis RW, McConnell J (2006) Political connections and corporate bailouts. J Financ 61: 2597-2635.

19. La Porta R, Lopez-de-Silanes F, Shleifer A, Vishny R (2000) Investor protection and corporate governance. J Financ Econ 58: 3-27.

20. Beiner S, Schmid MM (2005) Agency conflicts, corporate governance, and corporate diversification-Evidence from Switzerland.

21. Shabbier A, Padgett C (2005) The UK code of corporate governance: Link between compliance and firm performance. ICMA Centre Discussion Papers in Finance DP, UK. p. 17

22. Healy PM, Palepu KG (2001) Information asymmetry, corporate disclosure, and the capital markets: A review of the empirical disclosure literature. J Account Econ 31: 405-440.

23. Kapopoulos P, Lazaretou S (2007) Corporate ownership structure and firm performance: Evidence from Greek firms. Corporate Governance: An International Review. 15: 144-158.

24. Jensen MC, Meckling WH (1976) Theory of the firm: Managerial behavior, agency costs and ownership structure. J Financ Econ 3: 305-360.

25. Mishkin M, Vargha-Khadem F, Gadian DG, Watkins KE, Connelly A, et al (1997) Differential effects of early hippocampal pathology on episodic and semantic memory. Science. 277: 376-380.

26. Donaldson L, Davis JH (1991) Stewardship theory or agency theory: CEO governance and shareholder returns. Aust J Manag 16: 49-64.

27. Morgan EF (1980) Agency problems and the theory of the firm. J Polit Econ 88 288-307.

28. Fama EF, Jensen MC (1983) Separation of ownership and control. J Law Econ 26: 301-325

29. Dedman CJ, Nes J, Hanna TM, Dall RG, Baldwin KGH, et al. (2004) Optimum design and construction of a Zeeman slower for use with a magneto-optic trap. Rev Sci Instrum 75: 5136-5142.

30. Berle A, Means G (1932) The modern corporate and private property McMillian New York, NY. 